' Universidade Federal do Rio de Janeiro (UFRJ), Programa de Pós-Graduação

em Sociologia e Antropologia, Rio de Janeiro, RJ, Brasil

marcoatg@terra.com.br

Marco Antonio Gonçalves'

\title{
INTRÉPIDAS IMAGENS: CINEMA E COSMOLOGIA ENTRE OS NAVAJO
}

I was going to make you an intruder yourself.

(Al Clah apud Worth \& Adair, I972: 215)

O filme Intrepid shadows faz parte de Navajo Filming themselves, projeto precursor na antropologia visual, coordenado por Sol Worth e John Adair, ${ }^{\mathrm{I}}$ referente ao chamado cinema indígena. Em I966, Worth e Adair chegam na reserva navajo de Pine Springs, Arizona, com a intenção de estimular os Navajo a fazer filmes sobre sua própria sociedade. ${ }^{2} \mathrm{O}$ projeto testemunha o encontro da comunicação visual e da antropologia e se propõe como experimento autorreflexivo, posto que é, também, uma etnografia sobre todas as etapas do próprio processo de construção dos filmes pelos Navajo. O livro Through Navajo eyes, escrito pelos idealizadores do projeto em I972, procura avaliar os resultados da incursão imagética realizada pelos Navajo a partir das ideias iniciais sobre os argumentos dos filmes, das reflexões dos participantes sobre suas escolhas, de seus processos de captação e edição. Busca também explicitar as premissas conceituais do próprio projeto, concebido como experimento teórico. Worth e Adair partilham a concepção sobre o conceito de cultura, como um modo particular de conceber o mundo, que orienta, por sua vez, uma estrutura imagética subjacente. O modo de os Navajo pensarem e produzirem as imagens seria conduzido por sua visão de mundo, por princípios cosmológicos que estruturam suas noções de tempo, de espaço, de visível, de estático e de movimento.

Este artigo analisa Intrepid shadows, um dos oito filmes produzidos pelos Navajo, como modo de revisitar as ideias imagético-conceituais que embasaram o projeto. As imagens produzidas pelo navajo Al Clah são tomadas como 
literalmente intrépidas, ao produzir relação direta entre cosmologia e dispositivos imagéticos em radicalização da proposta de Worth e Adair: princípios que orientam concepções do mundo são constitutivos dos modos de dar a ver o mundo. Exploro, assim, as relações entre premissas culturais e estrutura fílmica, bem como as consequentes conexões entre cosmologia e cinema como regimes sensório-imagéticos que atualizam, complementam, alteram e contradizem os modos de pensar/ver e ver/pensar. O artigo toma as imagens do filme, as falas de Clah sobre seu processo de produção, as interpretações de Worth e Adair, e o material etnográfico navajo em busca de novos sentidos para sua apreensão. Trata-se de reinseri-los no debate por meio dos conceitos navajos de imagem, movimento, estático, sombra, máscara, caos e cosmo. O artigo se beneficia e se inspira nos conceitos e ideias desenvolvidos por Brasil (2012, 20I3, 20г 3a) que positivam o cinema indígena como possibilidade de indigenização do cinema (Brasil, 2013: 248), como capacidade de produzir um ponto de vista específico sobre o mundo. Brasil (2012: I I4) define como incompletude ontológica uma das propriedades do cinema indígena que encontra plena ressonância em Intrepid shadows: "o jogo entre campo, extracampo e antecampo - tão central em nossa teoria do cinema - se apresenta aqui [no cinema indígena] complexificado". Reconhece, portanto, que um dos traços definidores do cinema indígena se ancora no conceito de antecampo: o que está atrás da câmera insiste em passar para sua frente, produzindo uma operação complexa de reflexão e reflexividade (Brasil, 2013: 250). O antecampo vai ao encontro do cinema indígena uma vez que a proposição de muitos desses filmes, especialmente Intrepid shadows, é a de pôr em evidência a presença do invisível, o que problematiza uma concepção clássica do cinema estruturada no olhar e na imagem.

$\mathrm{O}$ artigo se organiza em quatro partes. Em "Atravessando o cinema pelos olhos navajos" situo o projeto de realização de filmes pelos Navajo ao identificar suas premissas, seus conceitos e suas proposições teóricas. Busco reconhecê-lo como proposição original da possibilidade de emergência do que conhecemos hoje como cinema indígena. "Intrépidas sombras" descreve e apresenta o filme de Clah e procura reconstituir para o leitor seu universo imagético. "Imagens, sombras, movimento" apresenta a teoria das imagens proposta por Clah, o que permite avançar a análise sobre a constituição das imagens no filme e sobre os princípios cosmológicos navajos. "Os Intrusos: Johnny Nelson, a máscara, o cineasta, a audiência" analisa o intruso como categoria central na estruturação do filme, como lócus da manifestação da alteridade e alteração que tem a ambição de converter, submeter pelo olho (da câmera, do homem, do cineasta, da máscara, da audiência) como possibilidade de olhar para o mundo navajo.

\section{ATRAVESSANDO O CINEMA PELOS OLHOS NAVAJOS}

A ideia de descrever o mundo como os Navajo o veem é a partida conceitual do projeto de Worth e Adair, derivada da concepção de que o cinema expressa 
não apenas ideias culturais, apresentadas como conteúdo do filme, mas uma estrutura manifesta numa forma navaja - ou seja, princípios estéticos estão presentes não apenas nos filmes, mas na arte, na língua, nos rituais e nos mitos. O cinema, tomado nessa dupla acepção, permitiria ver o mundo "através dos olhos navajos" ao mesmo tempo em que o próprio cinema é atravessado por essa forma e percepção estéticas de um mundo outro. ${ }^{3}$

Para Worth e Adair, se o projeto inicial assumia, de modo explícito, o ponto de vista malinowskiano, ele não se contentava em apenas apresentar o ponto de vista do nativo, mas almejava provocar, por meio do cinema, a emergência de um ponto de vista expresso pelos próprios nativos. Esse parece ser o gesto mais radical do projeto ao querer produzir um cinema indígena como possibilidade de formular e apresentar um modo de compreensão do mundo. O cinema passa a ser forma e conteúdo de uma cosmologia, juntando, de um modo não estranho aos Navajo, uma estrutura formal narrativa para uma visão de mundo. Essa dualidade unida ${ }^{4}$ entre forma e conteúdo faz sua aparição no filme Intrepid shadows quando a máscara yeibichei passa a exercer simultaneamente a função de ícone e de índice: é o próprio Ye'i, ser sagrado navajo e seu traço, seu resíduo, a possibilidade de a audiência adentrar aquele mundo através de seu olhar, tomando a perspectiva do intruso. A colisão entre ícone e índice que a máscara perpetua por meio das imagens permite essa "intrusão", ou seja, o atravessamento do cinema pelos olhos navajos.

A máscara yeibichai usada no filme foi criada especialmente por Al Clah para o filme. Nessa condição de imagem, ela instaura a própria possibilidade de emergência do cinema navajo. Situado nesse novo lugar, yeibichai é o ator cuja ação projeta seu significado para além do plano ao criar zonas de contato entre filme e mundo e ao proporcionar novos desafios e significações (Worth \& Adair, I972: 223). ${ }^{5}$

Há uma discussão ético-estética, característica da antropologia norteamericana pós-moderna, que percebe o projeto Navajo film themselves como mais uma manifestação da antropologia colonial ao se expressar por um viés paternalista (Ginsburg, I99I: 95; Dubin, I998: 74). Lewis (2010: 51) formula uma crítica ao projeto de Worth e Adair entre os Navajos nos seguintes termos: “Estavam mais interessados em encontrar 'autênticos' caminhos navajo de ver o mundo do que em abordar o contexto nacional em que o experimento foi realizado".

Essa percepção do projeto de cinema navajo advém do caso Yazzi, narrado logo no início do livro por Worth e Adair (I 972:5). Yazzi era um velho amigo e colaborador de Adair, e essa relação motivou uma primeira visita a Pine Springs com a intenção de apresentar o projeto para Yazzi e os Navajo. Yazzi pegunta: o filme vai produzir algum malefício às ovelhas? Adair responde: não. Yazzi então pergunta: o filme vai trazer algum benefício as ovelhas? Adair responde: não. Yazzi, então, interroga os autores: por que filmar? ${ }^{6}$ 
O caso Yazzi revela a complexa reflexividade e a preocupação ética manifestada pelos autores do projeto. A partir dessa conversa com Yazzi, Worth e Adair formulam um discurso contundente sobre o significado ético e epistemológico de sua pesquisa e seu potencial de reflexividade:

Assumimos que estudar como as pessoas se apresentam por meio das imagens seria benéfico e, certamente, não iria prejudicar ninguém. Temos, portanto, tentado descrever em grande detalhe, não só o que os Navajo fizeram quando aprenderam a usar a câmera, fazer filmes, olhar filmes, mas também o que nós, pesquisadores, fizemos e sentimos enquanto ensinávamos, observávamos e analisávamos. Recentemente tem havido muita discussão nos círculos antropológicos e sociológicos sobre a necessidade de uma atitude reflexiva na teoria etnográfica e na descrição. Estamos cientes de que nossos próprios modos de ver são mediados por nossa cultura. Pensamos que, nos descrevendo, descrevendo nossas preconcepções, atitudes e ações no campo permitiria ao leitor distinguir e comparar nossas percepções e as de nossos alunos navajos. Talvez nós também devêssemos ter a coragem de dizer desde o início que não sabíamos como esse trabalho poderia ajudar as ovelhas de Sam Yazzi, ou ajudá-lo a alcançar qualquer uma das outras coisas que ele tem de mais caro. Podemos dizer simplesmente que Sam nos ajudou. Ele cooperou quando deixou suas netas fazerem um filme sobre ele, chamado $O$ espírito navajo. E disse que pensou que o que estávamos fazendo era bom. Disse também que gostou dos filmes que foram feitos durante o projeto (Worth \& Adair, I972: 6).

Percebe-se, aqui, que o diálogo intercultural foi instaurado entre Worth, Adair e Sam Yazzi. A reflexividade proposta pelos antropólogos é o que transforma a própria pesquisa em experimento quando se assumem, conscientemente, os riscos que essa formulação implica. Um modo provocativo de repensar questões conceituais e teóricas colocando-as à prova a partir do que os próprios autores denominaram teoria etnográfica navaja, que passa a ser a medida, a chave e o limite para a reflexão e a reflexividade que implica os Navajo, o cinema, os filmes e eles mesmos no processo de produção do experimento imagético em Pine Springs (Worth \& Adair, I970: 9). A razão para fazer filmes expressa pelos antropólogos residia na problemática e nos limite das relações interculturais, percepção que os Navajo acabam por compartilhar e tomar como problemas na construção de seus próprios filmes.

Os trabalhos de Kluckhohn (Kluckhohn \& Leighton, I946; Kluckhohn, McCombe \& Fogt, I95I) sobre os Navajo foram construídos a partir das hipóteses linguísticas de Sapir-Whorf.? Baseiam-se numa relação expressiva entre língua e pensamento que, por sua vez, inspira a proposição de Worth e Adair (Ginsburg, I99I: 75). Do mesmo modo que a língua poderia veicular uma visão de mundo, a gramática do cinema navajo expressaria sua cosmologia. Deve-se, entretanto, reconhecer que, embora Worth e Adair tenham sido influenciados pelas etnografias que enfatizam essa qualidade da língua navaja como expressão de mundo, o projeto proposto não faz uma aposta literal de que a forma estruturada da gramática do cinema replica diretamente a cosmologia. A nova gramática do cinema engendrada pelos Navajo, se certamente evoca um modo 
navajo de perceber o mundo, não é uma "essencialização" tout court desse mundo em imagens. O pressuposto é que os princípios do mundo navajo, seus conceitos, estariam informando e provocando uma compreensão estética e uma organização das imagens nos filmes produzidos como diálogos criativos, aberturas, janelas para a percepção, compreensão e tematização de questões que os Navajo transpõem para seus filmes. Nesse sentido, os filmes navajos conjugam a reflexão e a reflexividade. Se são propositivos e reflexivos, nas questões conceituais sobre seu mundo são engendrados por processos de reflexividade. ${ }^{8}$ Situam-se, portanto, entre a proposição e o processo, a intenção e a realização. Essas questões caras ao cinema são especialmente importantes para os Navajo constituírem, simultaneamente, seu olhar sobre o mundo através das imagens, atravessar o cinema com esse olhar e ter, do mesmo modo, sua cultura atravessada pelo cinema.

Em todos os filmes realizados pelos Navajo, sejam aqueles que "aparentemente" focam o cotidiano, sejam aqueles caracterizados pela proposição mais abstrato-cosmológica de Intrepid shadows, encontram-se padrões narrativos referenciais na mitologia. É nesse sentido que Worth e Adair (I972: 260) assumem o pressuposto de que os Navajo comunicam sua visão de mundo por meio de seus filmes. Se pelo cinema podem criar novas narrativas visuais, elas, por sua vez, são construídas a partir de um estilo9 navajo. Portanto, para além do cinema e da cultura navajos, há um problema conceitual posto pelo projeto cinematográfico navajo que interroga os temas da cognição e das percepções interculturais. O balanço geral sobre os filmes realizados pelos Navajo indica que, nos dois tipos de filmes produzidos - os que foram classificados como "cotidianos" e o filme explicitamente conceitual (Intrepid shadows) -, realizam por caminhos distintos a mesma estrutura narrativa, fortemente ancorada numa ontologia navaja. De um lado, temos os Navajo que vivem na aldeia em Pine Springs e produzem seus filmes "cotidianos" orientados por princípios cosmológicos; de outro, temos Intrepid shadows, realizado por Al Clah que, com I 9 anos, vivia fora da comunidade de Pine Springs cursando o Institute of American Indian Art, em Santa Fé, o que lhe proporcionou alguma experiência com imagens - ele assistira a pelo menos ioo documentários antes de participar do projeto.

A escolha de Clah para participar do projeto envolveu graus distintos de ambiguidade. Por um lado, ele estava genuinamente interessado em participar, pois considerava uma oportunidade de aprender cinema, o que poderia trazer resultados para sua pretensa carreira artística:

Para mim, eu acho que preciso aprender mais, e o pagamento não faz nenhuma diferença, eu quero fazer isso... e quem sabe um dia poderei usar o filme ou algumas cenas para meu próprio uso artístico, de um ponto de vista artístico... e poder mostrar isso em San Francisco, eu posso mostrar alguns filmes lá, talvez uma sombra. Apenas uma sombra para ver como ela se move, suas cores... um uso expressivo e abstrato das cores (Worth \& Adair, 1972: 79). 
No começo do projeto, cada vez que Clah insistia em falar sobre as sombras mostrando as fotos e seu ensaio fílmico, Worth ficava reticente com a escolha que fizera por ele e chegou mesmo a escrever, em seus diários, sobre os riscos de Clah ter-se tornado um "artista clichê" ao exagerar, nas imagens que produzia, a influência advinda da Escola de Artes e dos filmes a que tinha assistido. Depois que assiste aos primeiros metros do filme Intrepid shadows, Worth desabafa:

As mesmas velhas coisas que ele havia feito antes. A máscara se movendo - as sombras - um homem andando segurando a câmera. Ele parece mais um estudante da Annenberg School. Eu deveria ser crítico e criticar seu material mesmo que esse pudesse ser adorado pela Ucla. Em todos os eventos, ele é um artista clichê-cineasta, e eu devo admitir minha falta de simpatia por seu desorganizado e não tão criativo "material artístico". Um Vanderbeek ele não é. Um Scorpio rising, ${ }^{\text {Io }}$ ele também não é. ${ }^{I I}$

Clah, que vivia na cidade e estudava em uma escola de artes, havia produzido um filme em uma linguagem da estética da chamada vanguarda experimental ocidental, em que se manifestam os princípios e referências da cosmologia navaja. Por isso Worth e Adair (I972: 26I-262) reconhecem que Intrepid shadows era, portanto, o filme mais "complexo" dos Navajo, sendo o mais apreciado pelos cineastas avant-gard e podendo ser considerado um marco do cinema experimental.

No contexto do workshop navajo, é possível perceber que o primeiro ensaio imagético realizado por Clah, Monkey bars, já manifestava essa vontade de juntar o "experimentalismo" à cosmologia navaja. As primeiras imagens são sobre as barras de ferro do trepa-trepa do playground da escola de Pine Springs e apresentam seus padrões geométricos e suas sombras projetadas no solo (Cf. Worth \& Adair, I972: 266).

Nas atividades do workshop sobre cinema ministrado por Worth e Adair, Clah expressava seu desejo de realizar um filme constituído de cenas que classificava como "inesperadas". Worth e Adair (I972: 25) percebiam que Clah pretendia, por meio de seu filme, fazer uma síntese de suas experiências em distintos mundos. Uma reconciliação entre o mundo navajo, seus princípios cosmológicos e o que aprendia como aluno do Instituto de Artes. Essa reconciliação dos mundos proposta por Clah encontrava acolhimento e significado no conceito de biodocumentary, ${ }^{12}$ formulado por Worth: "um filme feito por uma pessoa para mostrar como se sente a seu respeito e a respeito de seu mundo. Um modo subjetivo de mostrar o mundo objetivo que uma pessoa vê como 'real' [...] um modo específico de fazer filme que captura sentimentos e revela valores, atitudes e preocupações que estariam para além do controle consciente de quem faz o filme" (Worth \& Adair, I972: 25).

Um episódio significativo do qual Worth e Adair não tiram as devidas consequências é o fato de que, quando o filme Intrepid shadows foi exibido para os Navajo, uma mulher de 44 anos, que nunca tinha assistido a um filme 
antes, diz após a sessão: "Eu não entendo inglês, tudo foi narrado em inglês. As imagens foram explicadas em inglês. A razão pela qual eu não compreendi o significado é porque eu não compreendo inglês" (Worth \& Adair, I972: I30). Esse fato foi estranhado por Worth e Adair, uma vez que o filme não tem som. Essa incompreensão se situava, porém, na dimensão da língua, como se o filme tivesse sido narrado em inglês. Se tomarmos essa observação a sério perceberemos que o Intrepid shadows engendra o problema da narrativa em um contexto de recepção intercultural. Clah transpunha princípios da cosmologia navaja para um filme sem mundo, imagens sucessivas que queriam evocar os princípios cosmológicos navajos. Sua narração foi estruturada a partir de uma linguagem do chamado cinema experimental. Esse fato vem reforçar a ideia da construção do filme como situada entre as duas linguagens e provoca uma reflexão sobre sua abertura, sobre seus novos significados.

Clah insistia, desde o início, sobre um ponto durante o workshop com Worth e Adair (I970: 31-33): queria fazer um filme sobre algo que estava em sua cabeça. Essa concepção de Clah de não querer filmar ações no mundo cotidiano navajo ilumina sua intenção de produzir um filme conceitual e abstrato. Seu desafio era, portanto, fazer um filme que não se apoiaria naquele mundo imediato, mas seria antes uma declaração cinematográfica sobre um pensamento cosmológico. Nesse sentido, Intrepid shadows acentua essa abstração diferindo imageticamente dos demais filmes produzidos pelos Navajo. Essas características garantiram sua recepção como um "filme artístico". Esses enquadramento e recepção anglo-americanos parecem recusar o gesto inaugural do filme, que é o de presentificar, no plano do cinema, os princípios cosmológicos navajos. Assim, o filme coloca de uma só vez o paradoxo do cinema indígena. De um lado, os filmes são produtos da interconexão de mundos, realizados nas zonas de contato e por meio delas, e são, eles mesmos, meios de comunicação. De outro, situados nesse novo contexto, eles indicam, também, um acentuado grau de indeterminação, de incompreensão que os transforma em potências geradoras de uma política ontológica. Ao acentuar outra visão de mundo, tais filmes acabam por, literalmente, atravessar o cinema. Assim, o cinema navajo, e talvez isso possa ser estendido a uma vertente do cinema indígena, recusa um enquadramento que o aloja no gênero documentário, etnográfico ou experimental. O cinema indígena é, antes de tudo, a possibilidade de situar não apenas um olhar diverso. Ele situa um olho no plano do cinema, um olho imediato da experiência no sentido proposto pela síntese boasiana sobre percepção cultural: "o olho que vê é o olho da tradição". ${ }^{13}$ Um olho que apreende as imagens do mundo e as transforma em olhar no plano do cinema. Olho e olhar são, portanto, a síntese da construção da experiência cultural. Essa percepção encontra sua potência na literalidade do título do livro de Worth e Adair, Through Navajo eyes, situando-o, desde o início, como possibilidade de emergência de um cinema indígena. 
Clah, 45 anos depois da realização de seu filme, em 20 I I, diz que sua intenção ao realizar Intrepid shadows era acentuar a importância do equilíbrio, do viver bem, da natureza e do sentido de comunidade para os Navajo. Em sua percepção o filme é, agora, um legado para seus filhos e para as crianças poderem ver, hoje, esse mundo navajo. O filme Intrepid shadows emerge do desejo de produzir um filme sem mundo imediato para justamente poder dar a ver um mundo em toda a sua potência significativa. Construído assim, como um filme sobre uma ontologia, não resta outra alternativa senão a de impelir a audiência a experimentar esse olho mimetizado por sua câmera que Clah generosamente nos oferece, a de poder aceder ao olhar navajo por meio da sucessão de imagens que engendra. Esse olho nos submete a um modo navajo de compreender o mundo, e esse é o maior gesto político-cosmológico do filme. Gesto radical que corre os riscos da (in)compreensão, porém, parece ser a única possibilidade de adentrarmos como intrusos as dimensões da sombra, do movimento, do estático, do caos, da harmonia. Nesse sentido, o filme opera pelo olho uma conversão do olhar, situando-nos no ponto de vista dos objetos, da máscara, das sombras.

\section{INTRÉPIDAS IMAGENS ${ }^{14}$}

A primeira parte do filme apresenta a natureza em harmonia, movimentos naturais, movimentos lentos, pouco vento, sombras não muito pronunciadas. O filme se concentra sobre o movimento, e, em seus planos, o movimento é onipresente, sejam os de câmera ou os do mundo (aro que gira, bola que quica, vento que move os objetos, caminhadas, olhos da máscara que se movem). Os primeiros planos fazem um reconhecimento da paisagem: rochas, terra, árvores, céu e suas respectivas sombras. Surge um intruso que caminha por essa paisagem e com um graveto cutuca uma teia de aranha, destruindo-a. A partir desse momento o mundo entra em desequilíbrio, surge a sombra do aro que gira veloz e descontrolada. A máscara yeibechai toma o lugar do intruso e nos devolve seu ponto de vista sobre aquele mundo alterado. A máscara yeibechai vagueia atrás das árvores, é vista por entre os arbustos, olhando para o céu, olhando em todas as direções, e suas imagens são intercaladas com cenas contínuas da paisagem com ênfase nas sombras que giram. As sombras passam a ser grandes, longas e escuras. Surge o terceiro intruso, depois do homem que cutucou a aranha (Johnny Nelson), a máscara yeibichai, o próprio Clah passa a filmar sua sombra filmando, propondo uma fusão de sua sombra com a paisagem. A sequência final apresenta a sombra do aro girando durante I5 segundos até vermos a própria moldura do aro que, agora, gira em sintonia com sua sombra. Sombra e aro girando juntos em ritmo normal indicam o restabelecimento da harmonia do mundo. Vejamos sua narrativa. 
Uma folha de papel em que se lê "by Alfred Clah", em que se veem sombras de galhos movimentando-se com o vento. Folha de papel: "The intruder Johnny Nelson and...". As reticências encaminham para quem seria o outro intruso. Folha de papel: vê-se a máscara em primeiro plano desenhada sobre o papel. Panorâmica das árvores, seguida por planos curtos, também de árvores, seus galhos ainda sem movimento. A imagem (a câmera) se movimenta pelos galhos altos das árvores até chegar num plano mais próximo, em zoom, de um galho. Capim balança ao vento. Pedras em primeiro plano. Pedras em plano médio. Árvore caída. Pedra que brilha com a luz do sol. Copa das árvores. Galhos balançam lentamente ao vento. O movimento da câmera se funde com o movimento do vento, os galhos balançam. Galhos secos, e vemos, pela primeira vez, suas sombras no solo. Sombras projetadas na pedra. A vegetação. $O$ vento balança os arbustos. Sombras de galhos que balançam ao vento. Panorâmica sobre vegetação. Galhos balançam ao vento. No horizonte surge o intruso caminhando, passa pela câmera. O intruso continua andando. Procura algo no solo e carrega um pequeno graveto. Chapéu estilo cowboy, botas, calça escura e camisa social branca de manga comprida. Diante de um grande galho retorcido, o intruso arrodeia, se agacha, olha para o interior da galhada. Vemos além de suas costas a galhada e um fio que se destaca colado a um galho. Movimenta a cabeça como quem olha e procura algo. A teia de aranha. $\mathrm{O}$ intruso mexe a cabeça em outra direção. O centro da teia da aranha. Panorâmica da teia da aranha. O intruso com seu graveto cutuca a teia. Vemos, então, sua sombra que gira e impulsiona um aro. O intruso cutucando a teia de aranha. Seu rosto aparece pela primeira vez. Levanta-se como se olhasse para o aro que continua girando. O aro gira veloz pelos campos. O intruso o observa em seu giro. O intruso caminha. Procura algo. O intruso em primeiro plano. A máscara em close se movimenta. Toma o lugar do intruso e de seus movimentos de cabeça, continua procurando algo. Vemos a vegetação do ponto de vista da máscara. Máscara se movimentando. Olha para um lado e depois para outro. Continua andando. Closeup de seus olhos. O aro gira de forma violenta e descontrolada. Máscara olha para o aro girando. Aro, galhos. O aro segue girando em velocidade pelos campos. O aro gira sem parar. A sombra do intruso, suas botas. O intruso caminha. A sombra do intruso caminhando. A máscara caminha em direção à câmera. $\mathrm{O}$ aro gira rapidamente. Máscara e seus olhos em closeup. Botas caminhando. Os olhos da máscara se movimentam. As páginas de um caderno viram ao vento forte. Botas. Olho da máscara. Páginas do caderno virando. Uma bola quica no solo. A bola rola no campo. Botas andando. Máscara andando. Bota andando. Máscara andando, aproximando-se da câmera. Bola rolando. Bota andando. Máscara andando. Olha para o céu. Nuvens. Máscara se inclina olhando para o céu. Nuvens. Galhos retorcidos. Máscara olha para o céu. Galhos. Máscara. O aro girando no ar até cair em um arbusto e parar seu movimento. Imagem invertida de crianças girando num brinquedo. 
Ponta de um galho até a raiz da árvore. Imagem invertida de crianças girando num brinquedo. Ponta de um galho até a raiz da árvore. Imagem invertida de crianças girando num brinquedo. Ponta de um galho até a raiz da árvore. Olhos da máscara se movimentam, olham de um lado para o outro. Botas andando. Rosto do intruso, que procura algo. O aro girando, novamente. Máscara andando por trás de uma pedra até se ocultar num arbusto. Máscara andando e olhando. Troncos das árvores. Galhos que balançam ao vento. Árvores. Galhos. Árvores. Ponta dos galhos até a raiz. Galhos no alto das árvores. Chão. Ponta dos galhos até o solo. Arbustos. Árvores. Sombra da câmera filmando sua própria caminhada. Sombra da câmera filmando ganhando extensão, enorme. Sombra da câmera que filma sua sombra. Sombra das nuvens no solo. Galhos. Pontas dos galhos. Sombra do aro girando. O aro e sua sombra girando, agora, unidos e compassados.

\section{IMAGENS, SOMBRAS, MOVIMENTO}

Ao refletir sobre sua própria construção criativa com as imagens, Clah elabora uma distinção entre o engenheiro e o artista:

\footnotetext{
O engenheiro simplesmente repete as coisas mais e mais, edifícios, mecanismos. Mas o artista - é o trabalho de sua mente. Ele quer ver coisas, ele não tem que tocálas, ele tem que fazer com o espírito, recapturar a imagem em seu bloco. Lá ele toca o mundo, como eu toco, como se eu fizesse um retrato de você... Eu não posso dizer isso, eu não posso descrevê-lo, eu não posso tocá-lo. Essa é a face (apontando para seu bloco) (Clah apud Worth \& Adair, 1972: 216).
}

O engenheiro constrói os objetos por meio de uma prática, pelas mãos, pela repetição. Contrariamente, o artista produz a partir de sua mente. O artista, como ele se define fazendo cinema, "faz com o espírito", desenha a face de um homem sem tocar a face, produz uma imagem. Essa reflexão de Clah situa a imagem na ordem da mente, distinguindo-a do que não é "prática". Efetuando tal distinção, entretanto, ele não parece querer produzir uma diferença essencial entre a coisa em si ou a imagem sobre a coisa. Essa questão sintetiza de modo preciso e conceitual o objetivo de seu filme. Intrepid shadows é a imagem mental das coisas e não as coisas em si, embora a elas esteja remetida sensorial e visualmente. A experiência da sombra, portanto, é a proposta filosófica de seu filme que constrói imageticamente sua concepção de imagem: um modo de fazer cinema que pensa o próprio cinema no ato de sua feitura. As sombras são imagens mentais dadas no mundo e reconstruídas por Clah como imagens mentais em seu cinema. Portanto, cinema nessa acepção é um "fazer com o espírito", potência declaratória para os Navajo (ou para Clah) que o define como imagem de imagem. Devemos, porém, atentar para o fato de que, se Clah insiste na diferença entre a coisa em si (algo tocado, feito, prático) e imagem mental como da ordem do "espírito", não está enfatizando a canônica definição platônica de imagem senão invertendo-a. Platão, ${ }^{15}$ ao 
estabelecer uma separação entre níveis de representação que criam uma hierarquia entre as coisas em si e as formas como as coisas são apreendidas pela percepção humana, atribui à imagem propriamente dita (eikon) uma deficiência por tratar de uma ausência. Tal concepção, que eleva a imagem ao estatuto da representação do real, assegura a separação entre a coisa em si e sua imagem. Para Clah, o estatuto da imagem produzida na mente não é uma deficiência, mas sua própria potência, uma vez que a imagem de Clah não está a serviço da representação, mas de uma aparição, sendo literalmente uma sombra. Tampouco a noção de imagem de Clah se ajusta à noção de simulacro (eidolon), no sentido estético sugerido por Platão, que o define como o que rivaliza e compete com o modelo. A imagem para Clah não é algo da ordem da imitação e não corre o "perigo" de tomar o lugar do real, pois nessa acepção imagética não existiria propriamente um conceito de imagem regido pelos regimes de falsidade e verdade. A ideia de realizar uma imagem de uma imagem, um filme sobre a sombra, declara o rendimento da imagem como algo autônomo ao objeto e, por definição, não representacional. Essa intrépida imagem assombra (com o perdão do trocadilho) o tratado das "Três camas" proposto por Platão para compreender a imagem no Ocidente, ao inverter a fórmula de que imagem não é parecer mas ser, não é objeto mas sujeito. Nesse regime imagético navajo a imagem não é algo da ordem da visão, mas da percepção, e implica movimento, transformação, alteração. Clah quando grava o primeiro take do filme, que é o do metal girando e de suas sombras, diz que está interessado na imagem pelo seu aspecto de "trans - transformar - transformação" (Worth \& Adair, I972: 209).

Um curto bilhete que Clah escreve para Worth explicita este conceito de imagem: "O professor Worth visitou os Navajo do sudoeste. Ele passou aqui um tempo maravilhoso ensinando aos Navajo como colocar objetos em movimentos em tapes mágicos. Mágicos tapes são maravilhosos. Bons! Ele, o professor Worth, pinta nosso sol mágico, os deuses navajos. Ele poderia ser um bom navajo e talvez ele, o professor Worth, possa ficar e se tornar um bravo! Ele, o professor, pode dançar com as moças." ${ }^{16}$ (ver imagem na p. 646)

A referência que Clah usa para imagem são os moving objects que, capturados como imagens em movimento, são postos dentro de imagens, "mágicos tapes". O cinema, os tapes mágicos, são imagens em movimento que coincidem com a percepção navajo de apreensão de imagem como movimento e não apenas como sombra, mas, sobretudo, como sombras intrépidas.

No dicionário navajo-inglês ${ }^{17}$ a palavra chahash'oh significa sombra: ‘

"imagem escura projetada sobre uma superfície» ou "aquilo que existe apenas na percepção". Encontra-se também a palavra chaha'oh ${ }^{18}$ para designar "tonalidades", "sombra" e "sun shelter" (abrigo do sol). ${ }^{19}$ A sombra para os Navajo sintetiza seu conceito de alma e é referida como "o que está deitado sobre". A alma só pode ser morta pelo sol. No início do filme, o sol está forte, e as sombras são curtas e fra- 
INTRÉPIDAS IMAGENS: CINEMA E COSMOLOGIA ENTRE OS NAVAJO

646

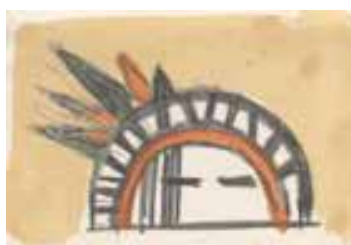
a marvelous time teaching ah Injun how to put moving objects on the magic tape. Magic tape was a marvelous um ah good.

He, the Ah Professor worth, him paints our magic sun, the Injun Gods. ONe um big and one ah tittle.

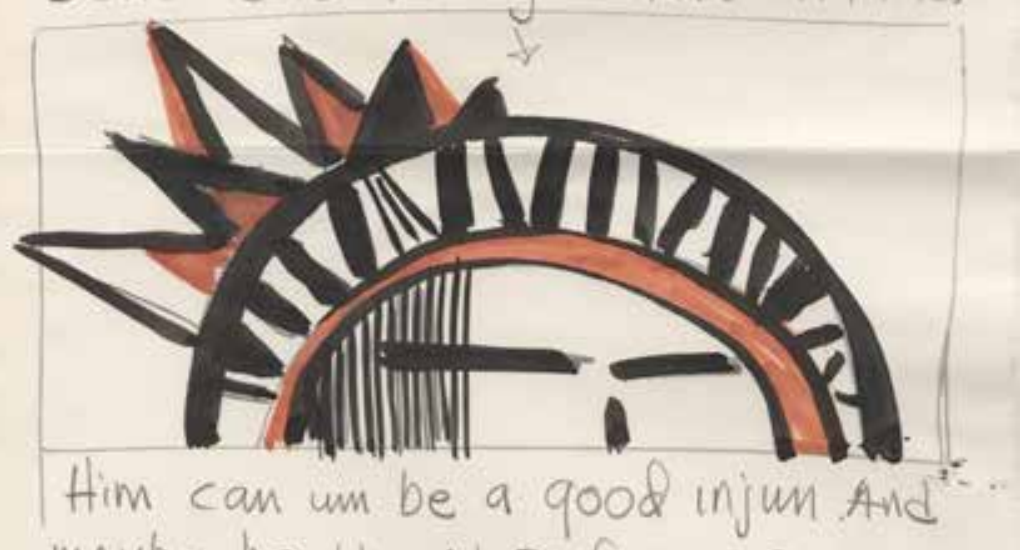
maybe he, the Ah professor, can stay and be ah brave. He, the Ah profecorre, um ah can dance with big girls sig w chief AL 
cas, mas o intruso interfere no trabalho da aranha e coloca o mundo em perigo (Worth \& Adair, 1972: 213).

A sombra está associada, para os Navajo, ao corpo, como uma parte dele, um sinal vital e, por isso, é comparada com o ar que sai do corpo, a respiração, ou o vento, que tem dinâmica própria. A sombra não pode ser separada do corpo e só as feiticeiras seriam capazes de projetar suas sombras para fora de seus corpos com o intuito de produzir malefícios (Newcomb, Stanley \& Wheelwright, I956: 55-58).

O conceito de sombra se manifesta, também, na correlação entre um cachorro e seu dono. Portanto, deve-se evitar fazer mal a um cachorro, pois o malefício volta-se para você mesmo. Outra ideia que associa sombra a malefício é a de que, quando se anda sob a lua cheia, é perigoso a sombra de uma coruja ser projetada sobre a pessoa que caminha, pois tal acontecimento, inevitavelmente, produz malefícios (Newcomb, I940: 52-56).

Para os Navajo a sombra é, portanto, extensão, vinculação, movimento por excelência, mudança, transformação, alteração coincidindo, assim, com a própria concepção dos mágicos tapes, que têm o poder, também, de capturar o movimento do mundo como imagem do mundo.

Clah tinha a preocupação manifesta de que seu filme tivesse imagens ícones que disparariam os significados do mundo. O título Intrepid shadows surge como um conceito que antecipa essa possibilidade imaginativa sobre o filme. "As sombras são destemidas" é o argumento que organiza as ações.

Clah escreve um poema no momento em que está preparando o argumento de seu filme. Um poema sobre o movimento que passa a ser um manifesto seu sobre a importância de produzir uma imagem mental como argumento de seu filme. O poema evoca imagens conceituais que se redobram sobre sua proposta fílmica. Embora o filme não tenha som, sua intenção inicial era sobrepor a leitura do poema como voice over às imagens. Formado por palavras-imagens, o poema agiria sobre as imagens do filme. Ele pensa, também, em gravar uma melodia tocada em sua flauta para as sombras dançarem, literalmente.

Vejamos seu poema ${ }^{20}$ (Worth \& Adair, I972: IOI-IO2):

Rodas, rodando, rodando ao redor, em voltas e voltas

Sombras esmaecidas visivelmente atrevidas que explodem em rotação sendo apenas movimento e tempo

A roda cinge uma viagem em círculo suas sombras marcam o caminho negro das suas voltas.

Roda, roda fiando uma faixa

sombras intrépidas girando

o vento irrompe nas copas das árvores produzindo um mosaico de sombras negras 


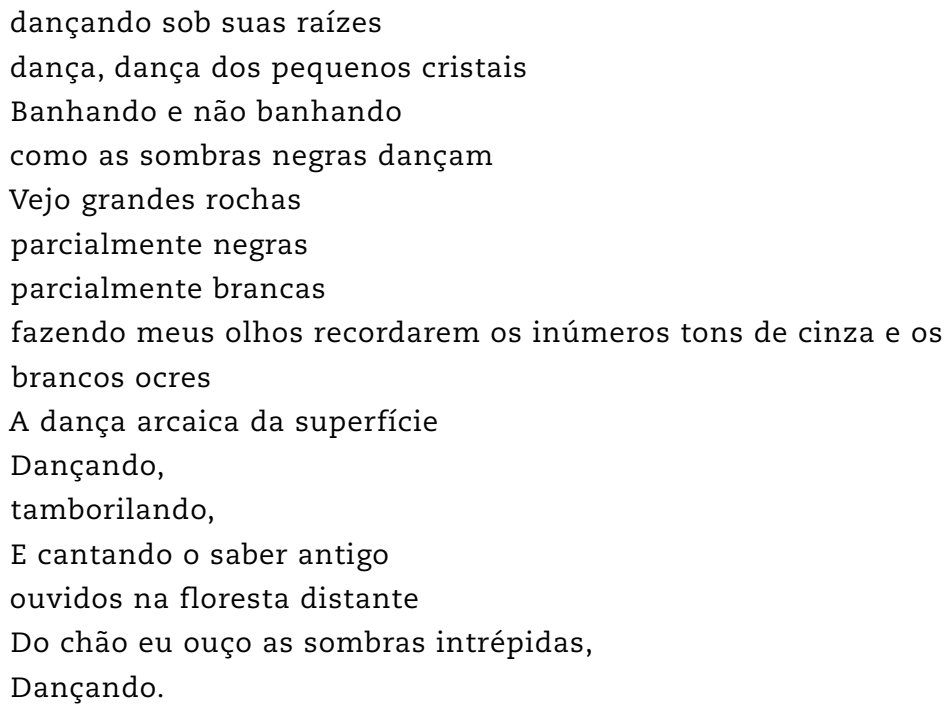

A poética de Clah é construtora das imagens que definem a cosmoestética do filme. Seu poema, assim como seu filme, não se constitui apenas de imagens sobre o movimento, mas é o próprio movimento. Essa recusa em representar, em falar sobre, é o que caracteriza a concepção imagética expressa por Clah. O poema é simultaneamente índice, argumento e roteiro do filme. Modo de organizar conceitualmente seu pensamento apresentando os referenciais da cosmologia navajo projetados em imagens mentais e visuais: "rodas", "rodando", "voltas", "sombras", "movimento e tempo", "viagem", "círculo", “caminho", "roda fiando uma faixa”, "sombras intrépidas", "girando", "vento”, “dançando".

Ao apresentar esse poema para os demais integrantes do grupo que participava do workshop, um deles, Johnny Nelson, imediatamente começa a falar sobre a importância das sombras e do seu significado de destemidas: “... as sombras envolvem o sol lá em cima". As sombras têm diferentes tamanhos e mudam rapidamente. Esse ponto é fundamental para compreender por que elas são intrépidas. Ele acrescenta: “a escuridão se aproxima do leste ${ }^{21}$... ninguém pode destruir a luz, e isso significa que ninguém pode destruir a sombra. Enquanto existir o sol, sempre existirá a sombra". Procurando acentuar, ainda mais, a importância da sombra e seu significado, Johnny Nelson narra uma passagem de um filme a que assistiu sobre uma guerra na Arábia em que, numa tomada aérea, mesmo com todas as barracas, os carros e o equipamento militar camuflados, restavam sempre as sombras projetadas. Nesse momento, Clah o interrompe e conclui dizendo: "as sombras sempre revelam a imagem [...] é por isso que eu vou fazer um filme sobre isso" (Worth \& Adair, I972: IOI-IO3).

Assim, o mais importante no filme não são os objetos em si, mas suas sombras, seus movimentos (Worth \& Adair, I972: I02). O desafio do filme é rea- 
lizar um filme sobre a sombra, sobre a imagem em si. Nessa acepção, uma das cenas mais icônicas é justamente aquela em que Clah filma sua própria sombra enquanto filma, quando a sombra do cinema (câmera) e sua imagem seguem juntas. ${ }^{22}$

Clah estava consciente de que poderia usar a linguagem dos filmes experimentais e de arte que assistira no Instituto de Arte em favor do que queria realizar (Worth \& Adair, I972: 79). Esse seu esforço de juntar domínios é sua declaração e proposta de fusão entre cosmologia e cinema. O filme, como ele o concebe, é um autorretrato de sua vida, da cultura navaja, do modo que ele coloca as coisas, literalmente, em movimento (Worth \& Adair, I972: 216). O autorretrato para Clah confunde-se com seu próprio filme, centra-se na questão do movimento do mesmo modo que o aprender e o educar, para os Navajo, es tão relacionados com o movimento, com o construir. Assim, Clah não separava o movimento das imagens do cinema dos movimentos de sua própria vida (Worth \& Adair, I972: 217).

Witherspoon e Peterson (I995) identificaram os princípios estruturantes do pensamento navajo como baseados numa relação entre simetria dinâmica e assimetria holística. Assimetria para os Navajo não expressa a falta de simetria ou de correspondência de forma. Caracteriza-se por uma inversão de forma e orientação. Essa percepção da assimetria ganha plena significação no corpo humano: os olhos apresentam simetria regular, mãos e pés exibem as simetria. A assimetria holística é justamente a ideia de um par binário que põe em relação oposições que se complementam ao mesmo tempo. Esse par binário estrutura o pensamento navajo e se expressa nas relações homem/ mulher, noite/dia, terra/céu. A assimetria holística cria, portanto, uma simetria dinâmica: "Pares binários constituem aspectos polarizados de um único fenômeno. As diferenças polarizadas criam um fértil e dinâmico fluxo e refluxo de contraste e complementaridade "(Witherspoon \& Peterson, I995: 24).

Os movimentos de ir para frente e para trás, de dar e receber são modelos de criar regularidade, complementaridade e dinâmica, como a percepção de que o verão sempre dá lugar ao inverno. o dentro/fora, o centro/periferia são também percebidos como pares assimétricos holísticos (Witherspoon \& Peterson 1995:75) e se associam, naturalmente, à ideia do intruso no filme Intrepid shadows.

Stasis/motion é o par fundante da assimetria holística: "Estático e ativo parecem ser a mais importante observação na cosmovisão navaja e na classificação do mundo" (Witherspoon \& Peterson I995: I9). Nesse contexto, o movimento é uma chave para acessar o sagrado: "Discurso, música e oração são o vento em movimento esculpido pelo poder da articulação humana" (McAllester, I979: 3 I32; Griffin-Pierce, I992: 72-73).

Nesse sentido todas as matérias e seres têm essa natureza dual expressa pelo estado estático e ativo. Nas palavras de Witherspoon (I977: 48): “O 
pressuposto subjacente a esse aspecto dualista de todos os seres e existências é de que o mundo está em movimento, as coisas estão constantemente a sofrer processos de transformação, deformação e restauração, e a essência da vida e do ser é o movimento".

Chalfen (I992) acentua que o movimento seria o conceito mais destacado em todos os filmes realizados pelos Navajo. As caminhadas são estruturais na composição das imagens. Os movimentos enquadram as histórias, definem sua estrutura narrativa. Os mitos navajos são estruturados como longas jornadas, viagens, deslocamentos que enquadram as narrativas. Portanto, os filmes navajos aprofundam essa dimensão das caminhadas dos heróis míticos entre os deuses como sua forma narrativa. Para os Navajo o movimento tem finalidade em si, distanciando-se, assim, de uma percepção do movimento expressa pela visão documental anglo-americana, segundo a qual o caminhar é apenas uma ponte entre planos e atividades nos filmes. O movimento não é, portanto, elemento de ligação entre planos, mas o que funda os próprios planos ao produzir sua densidade e tessitura imagética. Esse fato nos reenvia à questão da distinção entre olhares e percepções produzidos pelo cinema indígena e pelo chamado cinema ocidental. Novas significações sobre movimento, sombras, alteridade podem afetar as percepções correntes formuladas por uma estética visual ocidental, que encontra no cinema sua maior expressividade. Se o filme Intrepid shadows foi considerado excepcional entre aqueles produzidos pelos Navajo, temos que atentar para o fato de que ele tematiza, como os demais, de um ponto de vista estrutural, as mesmas questões sobre o movimento, a assimetria, ancorado numa estrutura mítica e no modo navajo de narrar histórias. Nesse sentido, as atividades de narrar mitos, o trabalho com joias de prata, as atividades cotidianas e o advento do cinema não podem ser mais ou menos "reais", pois todas expressam problemáticas postas por sua cosmologia (Cf. Worth \& Adair, I972: I52).

\section{OS INTRUSOS: JOHNNY NELSON, A MÁSCARA, O CINEASTA, A AUDIÊNCIA}

Existem múltiplos intrusos em Intrepid shadows: no plano do filme, Johnny Nelson e a máscara yeibichai; fora do plano, mas não menos central, o próprio Clah e a audiência, que se converterão em intrusos pelo processar do olhar. O intruso é, assim, estrutural no filme, um modo de enquadrar o movimento, princípio navajo que estrutura uma percepção do espaço e do tempo redobrada em seu cinema e que Intrepid shadows explora em toda a sua essência.

O intruso é seu centro de dispersão. Modo pelo qual adentramos o filme, intrusivamente; literalmente através de seus olhos. Intrepid shadows radicaliza o gesto de Worth e Adair ao relacionar cinema e cosmologia através dos olhos navajos. O filme toma para si o desafio de ver o mundo pelos olhos de outrem. Centrado na alteridade, nos intrusos e seus olhares, ele é a possibilidade de aceder, cognitiva e imageticamente, àquele mundo mental apresentado por 
imagens. Clah parece ter compreendido a problemática do cinema reverberada em seu filme como que em um fractal: ver um mundo através dos olhos de outrem e, como intruso, poder adentrar esse mundo.

O filme de Clah apresenta um personagem central, responsável por instituir, mediante sua ação quando cutuca e destrói a teia de uma aranha, a instabilidade no mundo. Depois de seu ato, tudo passa a girar, e as sombras tornam-se intrépidas. Esse acontecimento inaugural do filme é da mesma natureza das narrativas míticas em que um ato provoca a irrupção da desordem. Clah, assim, assume o intruso como a espinha dorsal do filme, um lócus que lhe dá sentido. Sua primeira ideia era a de realizar um filme em que a própria audiência pudesse colocar-se no lugar do intruso naturalmente, tomando o ponto de vista do "olho da câmera-intruso". Clah se deu conta, porém, de que apenas a perspectiva da câmera não era suficiente para ancorar um ponto de vista. Recorre, pois, à mis-en-scene, a olhos encarnados no mundo. Dizia que não estava interessado em tudo se movendo mas em algumas coisas movendo. Precisava de uma pessoa se movendo (andando) em seu caminho (Worth \& Adair, I972: 2I I).

O primeiro intruso é Johnny Nelson (colega no workshop fílmico navajo). Clah inicia o filme a partir da própria rotação da percepção de Johnny Nelson para que, nesse processo de "voltas" e de "giros", os espectadores pudessem aderir a seu olhar. Johnny Nelson, depois de muita insistência, aceita participar do filme com a condição de que Clah não filmase seu rosto. De acordo com o roteiro inicial apenas os pés de Johnny apareceriam, mas num determinado momento da filmagem ocorrem um close up ou outro, e Johnny resolve não mais participar do filme (Worth \& Adair, I972: I53). Essa interrupção levou Clah a introduzir o segundo intruso: a máscara yeibichai.

Worth e Adair (1972: 203-206) indicam a importância do movimento como meio de produzir um "evento" para que a ação ganhe sentido no mundo navajo. A ideia do intruso no filme deriva da ideia do movimento, uma vez que Clah diz que uma sequência de imagens sem uma pessoa andando na cena não teria o mesmo efeito, posto que é o evento-movimento que enquadra a cena. A recusa de Johnny Nelson em continuar as filmagens leva Clah a temer que o filme não possa ser finalizado - necessita do "real movimento". Clah esclarece esse ponto argumentando que coisas que se movem é que têm importância e, nesse sentido, o cinema é interessante para os Navajo porque passa a ser, sobretudo, movimento.

Aprofundando ainda sua concepção de movimento, ele acrescenta: considerando uma carta que você escreva e que pode reler muitas vezes, "ela não expressa por exemplo o quão vazio está um poço ainda que você escreva um livro inteiro sobre isso. Ainda que você escreva um livro inteiro sobre isso, é uma coisa parada. Você não pode expressar exatamente como um poço raso foi construído". Johhny Nelson acrescenta à observação de Clah: "O que quero 
realmente é algo que possa mover-se diante dos meus olhos..." (Worth \& Adair, I972: 203-204).

Por intermédio da figura do intruso articulam-se os principais conceitos do filme e adensam-se camadas de significados. O intruso como figura da alteridade é quem altera aquele mundo, e o filme testemunha essa alteração. "Cutucar a aranha" e destruir sua teia leva o mundo a um estado entrópico que se manifesta em imagens: "gira", "roda", "aros rodopiando", "sombras" movimentando. A destruição da aranha e de sua teia remete-nos à tecelagem, à fiação dos tapetes, arte navaja por excelência.

Na mitologia navaja a aranha é concebida como um dos criadores do mundo, quem o tece e o modela e, por isso, nunca deve ser interrompida na sua função de tecelã. Uma interferência no seu processo seria capaz de destruir o delicado equilíbrio do mundo. O equilíbrio é uma constante busca no mundo navajo, e qualquer interferência é capaz de lançar o mundo fora de sua engrenagem (Worth \& Adair, I972: 212-213).

Avancemos, ainda mais, no significado de tecelagem e da aranha de modo a sublinhar seus rebatimentos na teoria da imagem navaja e, em especial, compreender o destaque dado à aranha no filme Intrepid shadows.

Em um mito, a mulher-aranha surge ensinando às mulheres a arte da tecelagem. O mito narra que, naquele contexto, os deuses ainda não eram confiáveis e que as pessoas da terra passaram somente a conviver com os deuses quando uma mulher resolveu dar milho e outros bens para os deuses, instaurando uma relação de reciprocidade. Assim, o saber humano - e nele a tecelagem - foi aprendido dos deuses, em um pacto de relações de troca entre os deuses e os homens (Kluckhohn \& Leighton, I946: I25).

Os Navajo, portanto, aprenderam a tecer com a mulher-aranha, num tear construído de acordo com instruções dadas pelo homem-aranha (Parezo, I982: I 28-I29). Muitos autores enfatizam que os padrões do tecido sofreram grandes influências das relações com os brancos e com outros índios vizinhos. Desse modo, os "padrões atuais" dos Navajo são produto dessas relações nos últimos três séculos, o que demonstra que as imagem, os desenhos, o grafismo e a figuração estão presentes nos modos de se relacionar com os brancos e com os outros índios (Kent, I985:2).

A tecelagem é um dos elementos cruciais para compreender a ontologia da imagem navajo. Um dos padrões mais recorrentes e importantes é a forma "diamante" que, ao expressar a simetria quadrilateral, institui um modo perceptivo abstrato que convoca o olhar e a imaginação do observador para completar o padrão-desenho. ${ }^{23} \mathrm{O}$ padrão diamante surge interrompido nas bordas do tecido e, ao indicar seu transbordamento, aponta para sua ausência onipresente: "[os padrões] reduzem partes composicionais integrando-as em totalidades somatórias. Isso é muitas vezes conseguido através da adição de partes repetitivas que, juntas, formam um padrão geral. Totalidades somatórias e 
padrões gerais possuem as qualidades de simplicidade, clareza, objetividade e imediaticidade" (Witherspoon \& Peterson, I995: 74).

Um padrão que aparece de forma recorrente nos tecidos navajos, designado como o "buraco da mulher-aranha", está associado à percepção navaja de que a tecelã, ao tecer transforma-se em aranha, correndo o risco de seu espírito ficar preso na própria trama do tecido, na teia que urde. Nesse sentido, o "buraco da mulher-aranha" é, na verdade, uma rota de escape de modo que o espírito da tecelã possa sair do tecido (Cf. Kent, I985: 86-90; Newcomb, I940: 38). No filme de Clah, percebe-se que o olhar do intruso nos proporciona adentrar uma imagem-tecido em que o "espírito do olho" do espectador encontra-se preso à tessitura do mundo, agora, precipitado pelos redemoinhos, voltas e giros, em perpétuo desequilíbrio provocado pela irrupção das sombras destemidas naquele mundo. Ao mesmo tempo em que essa condição desarmônica do mundo é vivida nas imagens, o filme encaminha uma "rota de escape" do olho, quando a sombra retorna a seu referente, o movimento cessa, e o mundo volta a seu equilíbrio. Do mesmo modo que uma imagem-urdida, o filme trabalha com adição de partes que se repetem. Somatório de padrões minimalistas que formam um padrão geral, ele propõe, assim, que suas imagens tenham as mesmas qualidades atribuídas aos padrões da tecelagem: simplicidade, clareza, objetividade e imediaticidade.

Os padrões da tecelagem navaja apoiam-se em princípios cosmológicos em que o contraste entre assimetria e simetria precipita a ideia de "infinito", isto é, aquilo que permite ver para além do próprio padrão tecido no tapete, ícone que, por sua instabilidade, nos permite imaginar sua continuação para além de si mesmo. O filme, nessa acepção, encarna essa tessitura e, ao urdir imagens, transforma-se em ícone ou em um padrão geral a partir do qual podemos imaginar, para além do filme, uma cosmologia navaja.

É também a aranha que dá as penas aos gêmeos, penas que representam o fio da vida de modo a salvá-los do perigo. A mulher-aranha surge como perigosa, aquela que dispõe armadilha para as pessoas, colocando-as em apuros (Reichard, I950: 66). Assim, a aranha nas primeiras imagens do filme é, potencialmente, perigosa se um intruso interrompe seu processo de criação.

Clah dá continuidade à figuração do intruso no filme introduzindo uma máscara que ele mesmo fabrica usando papelão. ${ }^{24}$ Cria uma versão livre do padrão ritual da máscara yeibechai. Worth e Adair (I972: 2I6) acentuam que a construção da yeibichai por Clah introduz uma importante variação: os olhos foram feitos de modo tridimensional, controlados por barbantes e pedaços de madeira de modo que a máscara pudesse mexê-los, sugerindo que realmente observa a roda girando ditada pelo movimento de seus olhos. Observam, ainda, que a máscara de Clah apresentava duas linhas pintadas acima do nariz, forma que nunca aparece nas máscaras rituais. A máscara yeibichai presente nos rituais navajos é branca com I 2 penas de águia fixadas em seu topo. 
654

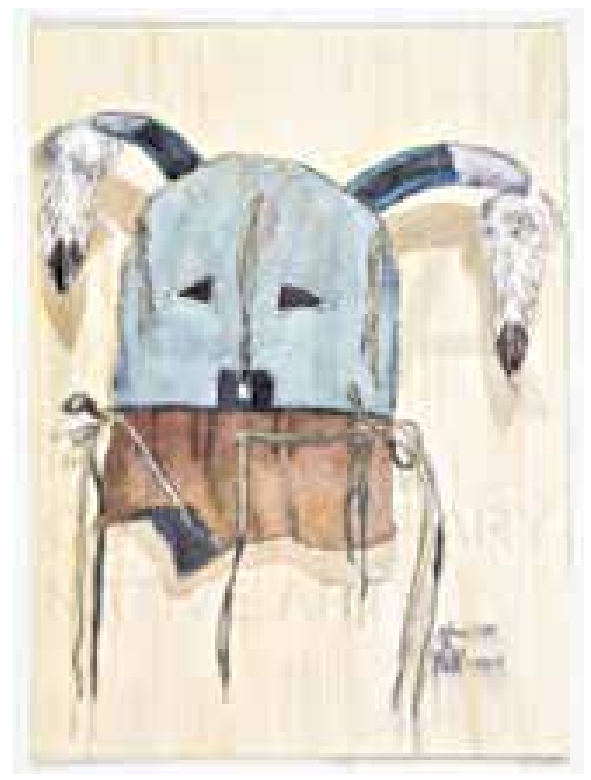

Muitos navajos de Pine Spring alertaram Clah sobre a introdução da máscara no filme por se tratar de um objeto sagrado. A cautela dos demais navajos em relação ao uso que Clah fazia da máscara em seu filme baseava-se no fato de essa máscara participar do ritual Nightway, desempenhando importante performance com o intuito de restaurar o estado de hózhó (descrito como equilíbrio). Nesse sentido, seu uso requer uma série de cuidados, uma vez que a realização de uma performance imprópria pode trazer graves consequências, como acentuar ainda mais o desequilíbrio em vez de propriamente restaurá-lo (Francis, I997: I5).

Intrepid shadows foi reexibido em Pine Spring para a comunidade navaja em 20 Io com a presença de Clah. Montoya (2013: 30) informa que a exibição reacendeu o debate sobre a aparição da máscara Ye’i no filme. Após amplo debate sobre a máscara, o consenso foi de que não se tratava da própria máscara, mas de uma interpretação dela, configurando a intenção de Clah de produzir uma máscara para o filme que não se confundisse com a máscara de Ye'i usada nos rituais navajos.

Clah, portanto, fez uma máscara cinematográfica, uma yeibichai para o cinema. Essa apropriação foi o modo de destacar algo do mundo para ressituálo na tela do cinema. A produção imagética de Ye'i revela a força da imagem cinematográfica, algo elaborado e criado no contexto do filme e que preserva sua autonomia do mundo navajo. 
Clah defende sua criação da máscara e sua inserção no filme afirmando que, do mesmo modo que ele próprio era um intruso, a máscara tomava seu lugar e poderia, assim, expandir seu ponto de vista. A máscara do filme olhando em todas as direções passa a testemunhar os eventos que estão ocorrendo no mundo. Desse modo, ele justifica que, por serem deuses, as máscaras são intrusos e, por isso, podem dar a ver "cenas que ninguém esperaria ver", como transformar em imagens os mitos e os deuses (Worth \& Adair, I972: 219). A máscara permite, assim, uma condensação do ponto de vista do intruso, e o que se encontra na mitologia ou cosmologia navajo agora é apresentado por meio do cinema.

O filme é constituído por duas sequências de intrusões: o desequilíbrio do mundo após o intruso desestabilizar a tecelagem da aranha e yeibechai testemunhando com seu olhar o mundo girando como consequência do distúrbio inicial.

A cosmologia navajo estrutura-se, como vimos, pela busca de harmonia, só conquistada por meio de determinadas performances que têm o poder de restaurar ou garantir a continuidade do equilíbrio entre o ser humano e os outros elementos do universo. Os Navajo foram criados como imagem dos "seres sagrados" com quem aprenderam determinados códigos de comportamento responsáveis por manter o equilíbrio do universo. Assim, a ideia de harmonia ou equilíbrio se traduz em "saúde" e "beleza" que, por sua vez, correm riscos de sofrer distúrbios oriundos de comportamentos inadequados, e, por isso, os Navajo devem seguir determinadas cerimônias e rituais. O maior dos rituais navajo é designado The Nightway, cerimônia curativa restauradora do equilíbrio. The Nightway é a invocação dos Yeis, categoria especial de seres que auxiliam os Navajo a pôr o cosmo em harmonia. O ritual é realizado durante nove dias no inverno, estação que não permite a incidência de raios solares e durante a qual as cobras hibernam. Destaca-se no ritual um grupo de 14 dançarinos, e entre eles está o líder yeibichai. No último dia do ritual, os dançarinos aparecem em público executando a dança yeibichai. A cerimônia termina com o canto do bluebird que celebra a felicidade e a paz simbolizada por esse pássaro (Cf. Faris, I990; Veltman, 200I; McAllester, I97I, I979; Mathews, I902, 1994).

Retornamos, aqui, a Intrepid shadows. Ao lhe dar destaque como personagem, ao assumir o ponto de vista de yeibichai, o filme procura, agora como ritual, restaurar a harmonia e o equilíbrio no mundo. A estrutura do filme caminha para seu final, que coincide, por sua vez, com o final do ritual, quando as sombras e as coisas se reintegram novamente e o mundo conquista o equilíbrio simbolizado no encontro da sombra do aro com o aro em si mesmo, quando ambos giram em harmonia. ${ }^{25}$

Os rituais de cantos em que surge yeibichai são rituais que visam restaurar o hózhó, conceito fundamental para os Navajo, que se traduz como or- 
dem incluindo, simultaneamente, a felicidade, a condição moral, o adequado, a saúde e o bem (Witherspoon \& Peterson I995: I5). Nesse sentido a ideia de colocar o mundo e as coisas em ordem ganha evidência na pintura de areia (saindpaiting).

Muitas das saindpaintings exibem simetrias radiais ou quadriláteras, aspectos que ressaltam para os Navajo a assimetria holística e a simetria dinâmica (Witherspoon \& Peterson, I995). Seguindo a análise de Worth e Adair (I972: 206), percebe-se que há uma compulsão dos Navajo para retornar ao começo, uma necessidade de fechamento que sempre engendra, por sua vez, uma abertura. As pinturas de areia são aparentemente fechadas pelos pontos cardeais, porém sempre abertas no leste. Do mesmo modo, o hogan tem sua porta para o leste, direção de onde vem a beleza e o bem. Outro exemplo de abertura é o padrão circular em zigue-zague do tecido na cesta de casamento, que é sempre interrompido para impedir o fechamento completo.

A questão do aro como objeto primordial do filme se associa à ideia de que o círculo (o aro), encontrado em muitos rituais navajos, veicula o conceito de fechamento, de espaços sob controle que o mal não pode penetrar (Reichard apud Worth \& Adair, I970: 3I-33). Porém, o que se observa no filme é que o aro posto em movimento perpétuo apresenta essa abertura, a possibilidade de uma transformação permanente quando não coincide com sua sombra.

A imagem, portanto, surge associada com o princípio da produção do bem-estar do mundo. De certo modo, os filmes realizados pelos Navajo enfrentam essa mesma questão ao procurar expressar em sua forma e conteúdo o princípio cosmológico hózhó. Intrepid shadows busca restaurar conceitualmente esse bem-estar, sendo o próprio filme o caminho trilhado para essa restauração. Os demais filmes encarnam demonstrações de uma estética do cotidiano e do viver bem, e em seu desenrolar as imagens caminham para esse estado de felicidade ou seus processos. Uma vez que o estado de hozhó é criado ou restaurado por ações rituais, os filmes criam ou restauram esse estado.

As máscaras yeibichai são os modos de os Navajo figurarem os Yei, deuses (Haile, I947). Os dançarinos e cantores yeibichai são como deuses personificados na figuração da máscara. Um dado significativo é que o ritual e a máscara yeibichai foram tardiamente produzidos como padrões de tecelagem entre os Navajo, só por volta dos anos I930, constituindo então o que se classifica como tecidos yeibichai. Esses tecidos são considerados por alguns pesquisadores uma produção voltada para um público anglo-americano que os adquire como arte turística, em que o ritual, os dançarinos/cantores, as máscaras e os personagens do yeibichai são reproduzidos (Valette, 200I; Kent, I985). Observase, assim, uma "virada figurativa" nos padrões de tecelagem navajos que, tradicionalmente, constituíam-se por grafismos produzidos na intricada e complexa trama que dava origem aos tecidos. Uma relação direta entre a figuração nos tecidos contemporâneos e o cinema navajo é o esforço de transposição do 
mundo navajo para imagens que dialoguem com o mundo dos anglo-americanos. No filme Intrepid shadows surge, do mesmo modo que na tecelagem, a intromissão de yeibichai, personificada em sua máscara, como figura de aproximação de mundos. As máscaras yeibichai marcam simbolicamente a restauração do mundo como pacificação das formas predatórias e desestruturadoras. Não parece ser por acaso que o ritual personificado por elas surja em sua potência figurativa nos tecidos consumidos como arte turística e no cinema navajo, marcadamente em um contexto de relações entre índios e brancos, em uma zona de contato que leva em conta os problemas históricos dessas relações e seus distúrbios. Nesse contexto, a tecelagem e o cinema são, eles mesmos, modos de restauração do equilíbrio de relações potencialmente perturbadoras entre índios e brancos.

Alguns símbolos pintados na máscara yeibichai são associados aos escalpos dos inimigos e os representam nesse momento do ritual. Nesse contexto, a alteridade da máscara é acentuada e representa não apenas os Yeis, seres de outros mundos, mas, também, os inimigos (Wyman, I983: 539-540). O escalpo adicionado à máscara enfatiza o mundo exterior, o que vem de fora, de outros índios. No filme, os intrusos e especialmente yeibichai apresentam as imagens alteradas. Vale enfatizar que há aqui um acoplamento na concepção navaja entre alteridade e alteração, sendo o intruso o lócus de sua manifestação. O intruso pressupõe relações entre planos distintos, deuses e homens, os Navajo e os demais índios, os Navajo e os brancos. Portanto, situado no plano do cinema, o intruso, marca essa possibilidade do diálogo intercultural tendo como precondição os princípios essenciais da experiência cinematográfica navaja: alteridade e alteração.

Clah, ele próprio, era um intruso em Pine Springs, uma vez que foi convidado pelos pesquisadores para integrar a equipe de estudantes navajos. Durante sua estada em Pine Springs, Clah morou com os pesquisadores no dormitório e nunca foi convidado para nenhum hogan navajo. Clah foi classificado pelos pesquisadores e pelos Navajo como introspectivo, hostil e competitivo. Comportava-se, literalmente, como intruso, destemido como suas sombras, o que gerava, entre os Navajo, muitos conflitos. Desse ponto de vista, o filme é, também, um comentário pessoal e cultural sobre sua própria condição de outsider (Worth \& Adair, I972: 209). Portanto, Clah é o intruso onipresente do filme. Clah reconhece essa onipresença afirmando que a máscara é o seu personagem, é literalmente ele mesmo (Worth \& Adair, I972: 22I); por isso ele declara que sua mente e seu corpo estão presentes no filme. ${ }^{26}$ Referindo-se ao primeiro intruso, Johnny Nelson diz: "eu vesti a camisa branca e a calça, ele é meu espírito". Para Clah, por ter um corpo e um espírito, o filme pode agir sobre as emoções das pessoas (Worth \& Adair, 1972: 220). Clah reconhece que essa sua condição de metamorfosear-se em intrusos é o que garante que a audiência se torne, ela mesma, intrusa. Deriva dessa percepção sua frase-síntese: “Eu ia 
658

transformá-lo, você mesmo, em intruso". A inserção do intruso, pois, não é apenas um artifício de observação daquele mundo, mas um projeto de conversão dos espectadores em intrusos para que possam aceder assim à percepção de que as sombras têm agência, são mais do que extensões de imagens.

Recebido em 28/og/20I6 | Aprovado em 3I/IO/20I6

Marco Antonio Gonçalves é professor do Programa de PósGraduação em Sociologia e Antropologia (PPGSA) da Universidade Federal do Rio de Janeiro (UFRJ). Fez seu mestrado (I989) e doutorado (I995) no Programa de Pós-Graduação em Antropologia Social (PPGAS) do Museu Nacional/UFRJ. É autor de O mundo inacabado: ação e criação em uma cosmologia amazônica (200I); O real imaginado: etnografia, cinema e surrealismo em Jean Rouch (2008) e Traduzir o outro: etnografia e semelhança (20II). 


\section{NOTAS}

I Sol Worth (I922-I977) foi um artista, pintor, professor de comunicação visual da Annenberg School for Communication, Universidade de Pennsylvania. Dirigiu Teatteri, importante filme que faz parte da coleção permanente de filmes do $\mathrm{Mu}$ seu de Arte Moderna de Nova York. Foi dele a ideia de realizar o experimento cinematográfico entre os Navajo e de testar seu conceito de biodocumentary. John Adair (I9I3-I997), foi professor de antropologia da San Francisco State University, iniciou seus estudos em antropologia nos anos 30 em Columbia, como aluno de Ruth Benedict, mas doutorou-se na Universidade do Novo México. Realizou pesquisa entre os Zuni e Navajo, dirigindo filmes e publicando artigos e livros sobre os Navajo de Pine Springss.

2 Participaram do projeto: Sol Worth, John Aldair e Richard Chalfen (orientando de Worth). As preliminares do projeto começam em março de I966, quando Adair e Worth viajam a Pine Springs com o intuito de organizar o projeto com os Navajo e saber se estariam interessados em participar. Durante junho e julho, oito horas por dia e cinco dias por semana, coordenam um workshop com objetivo de viabilizar que os próprios Navajo produzam seus filmes de modo que tenham controle sobre todas as etapas do processo. Durante toda a duração do projeto, os alunos Navajo (Mike Anderson, Al Clah, Susie Benally, Johnny Nelson, Mary Jane Tsosie, Maxine Tsosie, Susie Benally's mother, Alta Kahn) recebiam o pagamento de um salário mínimo americano e realizaram I6 filmes, sendo oito curtos ensaios - The pinlon tree, Mike Anderson, 2'; The summer shower, Johnny Nelson, 2'; The navajo horse, Johnny Nelson, 3'30; John Adair hangs out the laundry, Mary Jane Tsosie, Maxine Tsosie, 2'; The boys on the seesaw, Maxine Tsosie, 1:30'; The monkey bars, Al Clah, 2'; The swing, Susie Benally, 2'; The ants, Mike Amdersom, 2' - e oito filmes: A Navajo weaver, Susie Benally, 20'; Second weaver, Alta Kahn, 8'53; Old antelope lake, Mike Anderson, I2'37; Intrepid shadows, Al Clah, I5'; The navajo silversmith, Johnny Nelson, 20'; The spirit of the Navajo, Mary Jane Tsosie, Maxine Tsosie, 20'; The shallow well, Johnny Nelson, 20'; Untitled film, Alta Kahn, Io'. Os filmes tiveram sua world première em Pine Springs e depois foram exibidos no Flaherty Seminar (I966), Swarthmore College (I966), Washington, DC (I967), Festival Dei Popoli, Florença, Itália (I967), Uni- 
versity of New Mexico e National Museum of the American Indian (I980), Navajo Nation Museum, Arizona (20II). Adair retornou em I970 a Pine Springs para recontatar todos os cineastas navajo com a intenção de dar continuidade ao projeto e fazer de Pine Springs uma unidade de produção de filmes navajo, em que eles mesmos iriam ensinar para outros navajo o processo de produzir filmes, projeto que, entretanto, não foi implementado por falta de fundos.

3 Essa potência do cinema indígena é expressa por Brasil (20 I 2: I I5): “... é como se o cinema indígena reelaborasse a tradição escópica ocidental a partir de sua própria cosmologia, de sua própria perspectiva."

4 Uso aqui um conceito de Eisenstein que exprime uma possibilidade estética do cinema que estreita uma relação entre forma e conteúdo (Gonçalves, 2012:I73).

5 Desenvolvo mais adiante as questões advindas do uso que Clah faz dessa máscara no filme.

6 A participação de Yazzi no projeto envolveu distintos graus de ambivalência. Worth, em seus diários, menciona que teve que negociar com Yazzi uma compensação financeira para que aceitasse participar do filme realizado por suas netas: Yazzi exigia dez dólares das netas e dez dólares de Worth para autorizar sua aparição no filme The spirit of the Navajo. (Cf. Worth, B I4FF30P297 in http://www.penn.museum/sites/navajofilmthemselves/).

7 Essa hipótese ficou conhecida como Sapir-Whorf e postula que as línguas em seu aspecto formal veiculam uma visão de mundo. Os autores usaram o conceito de Weltanschauung (visão de mundo) formulado pelo romantismo alemão sobre língua e cultura elaborado por Wilhelm von Humboldt (I988). Ver a respeito especialmente Stoking Jr. (I996), Gonçalves (2009).

8 Caixeta de Queiroz (2008:I2 I) chama atenção para uma das propriedades do cinema indígena: a capacidade de filmar e comentar a cena na simultaneidade, o que engendra o processo de reflexão e reflexividade. Ver Brasil (2013) sobre a lógica do antecampo e a importância da instauração do processo de reflexividade para o cinema indígena. 
9 Ver Bateson (I987:I08) para a ideia de estilo como um sistema de transformação que busca mais a veiculação de um código do que uma mensagem.

Io Stan Van DerBeek (I927-I984) foi um cineasta experimental americano. Scorpio rising (I964) é um filme cult, dirigido por Kenneth Anger.

I I Ver <http://www.penn.museum/sites/navajofilmthemselves/citations-worths-perception-of-the-students/>. Acesso em I I maio 2016 .

I 2 Para uma ampliação da discussão sobre etnografia e subjetividade e os conceitos de etnobiografia e biodocumentário, ver Gonçalves, Cardoso \& Marques, 2013.

I3 Ver especialmente Cavalcanti (2005: 3I9).

I4 Dada a dificuldade de visualizar esse filme nas plataformas visuais da internet, recorro aqui a uma descrição de seus planos seguindo pari passu suas imagens de modo a reconstituir para o leitor o universo imagético de Intrepid shadows.

I5 Ver o ensaio sobre as três camas (Platão, I997).

I6 Esse bilhete foi reproduzido no site oficial do projeto $\mathrm{Na}$ vajo Filming Themselves. Disponível em: <http://www. penn.museum/sites/navajofilmthemselves/the-films-2/ intrepid-shadows/>. Acesso em I I maio 2016.

I7 Ver <https://en.glosbe.com/en/nv/shadow>. Acesso em I4 abr. 2016.

I 8 Como na sentença Dził bichaha'oh kéyah bik'est'i' (A sombra das montanhas cobriu a terra).

I9 A casa da sombra é feita de troncos de árvores e coberta com folhagem. É um local importante na organização espacial de uma comunidade navaja. Muitas casas têm essas estruturas acopladas que são as casas de sombra durante os meses de verão. O importante acentuar é que uma chaha'oh nunca é considerada pronta, terminada, uma vez que exige constante cuidado. Assim, esse espaço se associa naturalmente à ideia de sombra seja conceitualmente, seja fisicamente. Essa "casa da sombra" tem múltiplos usos. É lugar comum de se cozinhar, cortar a carne. É comum, hoje em dia, ver uma estrutura formada por quatro postes-troncos coberta de ramagens abrigando ao seu redor mesas, cadeiras o que define esse espaço como espaço de encontro. 
Essa casa da sombra é bem distinta de uma hogan (casa tradicional/ritual navajo). Enquanto o hogan é impermeável, fechado, sem janelas, a casa da sombra é permeável, aberta, vazada (Kelley \& Whiteley, I989:I24).

20 Tradução minha do original:

Wheels, wheeling, wheeling around, and round, and round Rusty shadows pushing outward and bursting into spin leaving nothing but motion and time.

The wheel belt traveling into circle letting its shadows marking it black highway between its wheels.

Around, and around the wheel and the belt spins, the intrepid shadows spinning.

The winds, nursing the treetops with little break-up puzzles of black shadows dancing underneath its root Dance, and dance of little pebbles

Bath, and not bath as the black shadows dance.

I see big rocks partially black partially white making my eyes recall the countless painted of grays and ochre whites the archaic dance on the surface. Dancing, And drumming, And singing of the ancient lore Are heard in the distant forest. On the ground I hear the intrepid shadows Dancing.

2 I A ideia da sombra vir do leste parece estar associada, na etnografia navaja, à ideia de hogan, a casa ritual como arquitetura do mundo. A partir de seu centro demarcam-se os pontos cardeais. Não parece ser coincidência que a entrada da hogan seja a leste, e que leste se associe ao pensamento e à sombra (o sul é onde os planos existem; do oeste vem a vida; do norte, a sabedoria).

22 Ver Brasil (2013: 250): "A exposição do antecampo provoca, em contrapartida, o atravessamento (e mesmo a fratura) 
do dialogismo pela reflexividade [...] A reflexividade, por sua vez, acusa o caráter artificial, mediado e fraturado do diálogo".

23 Ver especialmente Lagrou (2007) sobre as qualidades dos grafismos caxinauás como estilo de ver e pensar e como operam a passagem do visível ao invisível no mundo ameríndio.

$24 \mathrm{Em}$ I964, portanto antes do projeto fílmico com os Navajo, Clah já havia reproduzido uma máscara muito semelhante à de Ye'i, em papel e aquarela: Untitled Navajo Blue Mask, watercolor on paper, I964, by Al Clah, (N-I226), The Museum of Contemporary Native Arts, Santa Fe, New Mexico. Ver:<http://ehillerman.unm.edu/ehillerman/node/ I 785 \#sthash.I7CPlnS7.dpuf>. Acesso em 30 nov. 2016.

25 A última cena do filme é a mais longa sequência do aro rodando. Clah explica que foi a mais trabalhosa, uma vez que para fundir o aro e sua sombra dependia de um momento de sombras específicas durante o dia que daria esse efeito no filme (Worth \& Adair, I972: 220).

26 Ver Caixeta de Queiroz (2008: I I7-I I8) para quem "o cinema indígena é um cinema mais dos corpos do que das palavras, porque sua ontologia deposita nos corpos um lugar central para a constituição de sua socialidade".

\section{REFERÊNCIAS BIBLIOGRÁFICAS}

Bateson, Gregory. (1987). Steps to an ecology of mind. Londres: Jason Aronson Inc.

Brasil, André. (2013). Mise-en-abyme da cultura: a exposição do "antecampo" em Pi'õnhitsi e Mokoi Tekoá Petei Jeguatá. Significação, 40/40, p. 245-267.

Brasil, André. (20I3a). Formas do antecampo: performatividade no documentário brasileiro contemporâneo. Revista Famecos, 20/3, p. 578-602.

Brasil, André. (20I2). Bicicletas de Nhanderu: lascas do extracampo. Devires, 9/ I, p. 98-i I7.

Caixeta de Queiroz, R. (2008). Cineastas indígenas e pensamento selvagem. Devires, 5/2, p. 98-I 25. 
Cavalcanti, Maria Laura Viveiros de Castro. (2005). Cultura e razão prática. Mana, I I/I, p. 317-320.

Chalfen, Richard. (I992). Picturing culture through indigenous imagery: a telling story. In: Crawford, Peter \& Turton David (orgs.). Film as ethnography. Manchester: Manchester University Press, p. 222-24I.

Dictionary Navajo-English. Disponível em: <https://glosbe. com/en/nv/.>. Acesso em 30 nov. 2016.

Dubin, Margaret. (1998). From artful ethnography to ethnography art: the enduring significance of the Navajo film project. Visual Anthropology Review, I4/I, p. 73-75.

Faris, James C. (I990). The nightway: a history and a history of documentation of a Navajo ceremonial. Albuquerque: University of New Mexico Press.

Francis, Sandra T. (1997). The Y'e'ii bicheii dancing of nightway: an examination of the role of dance in a Navajo healing ceremony. Tese de Doutorado. The Ohio State University.

Ginsburg, Faye. (I99I). Indigenous media: Faustian Contract or Global village? Cultural Anthropology, 6/I, p. 92-I I 2. Gonçalves, Marco Antonio. (20I 2). Sensorial thought. Cinema, perspective and Anthropology. Vibrant, 9/2, p. I6I-I83.

Gonçalves, Marco Antonio. (2009). Traduzir o outro: etnografia e semelhança. Rio de Janeiro: >Letras.

Gonçalves, Marco Antonio; Cardoso, Vânia \& Marques, Roberto. (20I3). Etnobiografia: subjetividade e etnografia. Rio de Janeiro, 7 Letras.

Griffin-Pierce, Trudy. (I992). Earth is my mother, sky is my father: space, time, and astronomy in Navajo sandpainting. Albuquerque: University of New Mexico Press.

Haile, Father Berard. (1947). Head and face masks in Navajo ceremonialism. St. Michaels: St. Michaels Press.

Humboldt, W. von. (1988) [1836]. On language: the diversity of human language structures and its influence on the mental development of mankind. Cambridge: Cambridge University Press.

Kelley, Klara B. \& Whiteley, Peter M. (I989). Navajoland: family settlement and land use. Tsaile: Navajo Community College Press. 
Kent, Kate Peck. (1985). Navajo weaving: three centuries of change.. Santa Fé: School of American Research Press.

Kluckhohn, Clyde \& Leighton, Dorothea. (I946). Navaho. Cambridge: Harvard University Press.

Kluckhohn, Clyde; McCombe, Leonard \& Vogt, Evon. (I95I). Navajo means people. Cambridge: Harvard University Press.

Lagrou, Els. (2007). A fluidez da forma: arte, alteridade e agência em uma sociedade amazônica (Kaxinawa, Acre). Rio de Janeiro: Topbooks.

Lewis, Randolph. (2010). The new Navajo cinema: cinema and nation in the indigenous Southwest. The Velvet Light Trap, 66, p. 50-6I.

Matthews, Washington. (I994) [I896]. Navaho legends. Salt Lake City: University of Utah Press.

Matthews, Washington. (I902). The night chant: a Navajo ceremony. In: Memoirs of the American Museum of Natural History VI. Nova York: Knickerbocker Press.

McAllester, David P. (I979). A paradigm of Navajo dance. Parabola, 4/2, p. 28-35.

McAllester, David P. (I97I). Review of Night and Daylight Yeibichei. Ethnomusicology, I5/2, p. I67-I70.

Montoya, Teresa. (2013). Will making movies do the sheep any good?: new interpretations of the Navajo Film Project. Center for Media Culture and History, New York University (mimeo).

Newcomb, Franc Johnson. (I940). Navajo omens and taboos. Santa Fé: Rydal Press.

Newcomb, Franc Johnson; Fishler, Stanley A. \& Wheelwright, Mary C. (1956). A study of Navajo symbolism. Papers of the Peabody Museum of Archaeology and Ethnology, Harvard University, $32 / 3$.

Parezo, Nancy J. (I982). Navajo sandpaintings: the importance of sex roles in craft production. American Indian Quarterly, 6/I-2, p. I 25-I48.

Platão. (I997). Os Pensadores. São Paulo: Abril Cultural.

Reichard, Gladys Amanda. (1950). Navaho religion: a study of symbolism. Nova York: Bollinger Foundation.

Stocking Jr., George (org.). (I996). Volksgeist as method and 
ethic: essays on Boasian ethnography and the German anthropological tradition. Wisconsin: The University of Wisconsin Press.

Valette, Rebecca \& Valette, Jean-Paul. (200I). Weaving the dance: Navajo Yeibichai textiles (I9I0-I950). Arizona: Adobe House.

Veltman, Joshua. (200I). Nightway Yeibichai songs and the Navajo worldview. Disponível em: <http://www.uu.edu/ personal/jveltman/research/yeibichai/yeibichai.text. html.>. Acesso em I8 abr. 2016.

Witherspoon, Gary. (1977). Language and art in the Navajo universe. Ann Arbor: University of Michigan Press.

Witherspoon, Gary \& Peterson, Glen. (I995). Dynamic symmetry and holistic asymmetry in Navajo and Western art and cosmology. Nova York: Peter Lang.

Worth, Sol. (20II). Papers. Disponível em: <http://www. penn.museum/sites/navajofilmthemselves/citations-worths-perception-of-the-students/.> Acesso em I4 abr. 2016. Worth, Sol \& Adair, John. (1972). Through Navajo eyes: an exploration in film communication and Anthropology. Albuquerque: University of New Mexico Press.

Woth, Sol \& Adair, John. (I970). Navajo filmmakers. American Anthropologist, 72, p. 9-34.

Wyman, Leland Clifton. (1983). Navajo ceremonial system. In: Ortiz, Alfonso (org.). Handbook of North American Indians. Vol. 9: Southwest. Washington, D. C.: Smithsonian Institution, p. 536-557. 
Palavras-chave

Cinema indígena;

Cosmologia;

Navajos;

Imagem;

Antropologia visual.
Keywords

Indigenous cinema;

Cosmology;

Navajos;

Image;

Visual Anthropology.
INTRÉPIDAS IMAGENS: CINEMA E COSMOLOGIA

\section{ENTRE OS NAVAJO}

Resumo

Este artigo analisa Intrepid shadows, um dos oito filmes produzidos nos anos I96o pelos Navajo como modo de revisitar as ideias imagético-conceituais que embasaram o projeto Navajo filming themselves, coordenado por Sol Worth e John Adair. As imagens produzidas pelo navajo Al Clah são tomadas como literalmente intrépidas, ao produzir relação direta entre cosmologia e dispositivos imagéticos. Exploro, assim, as relações entre premissas culturais e estrutura fílmica, bem como as consequentes conexões entre cosmologia e cinema como regimes sensório-imagéticos que atualizam, complementam, alteram e contradizem os modos de pensar/ver e ver/pensar.

\section{INTREPID IMAGES: CINEMA AND COSMOLOGY} AMONG THE NAVAJO

\section{Abstract}

This article analyzes Intrepid shadows, one of the films produced by the Navajo in the sixties, as a way to revisit the conceptual ideas that supported the project Navajo filming themselves, coordinated by Sol Worth and John Adair. The images produced by the Navajo Al Clah are taken literally as intrepid, producing a direct relationship between cosmology and cinema. I explore the relationship between cultural assumptions and filmic structure and the consequent connections between cosmology and cinema as sensory-imagery systems that supplement, alter and contradict the ways of thinking/seeing and seeing/thinking. 